\title{
Exposure time of virgin coconut oil against oral Candida albicans
}

\author{
Lui Dwen Tjin*, Ame Suciati Setiawan**, Emma Rachmawati** \\ *Department of Oral Surgery, Kuala Lipis Hospital, Malaysia \\ **Department of Oral Biology, Faculty of Dentistry, Universitas Padjadjaran Bandung, Indonesia
}

\begin{abstract}
Introduction: Virgin coconut oil (VCO) is an oil which is purely made as a product of the coconut palm and has been used for centuries in the culinary industry and the medical field. Currently, VCO is used widely in medical field due to its effectiveness as antibacterial, antiviral, and antifungal properties. Objective of this experimental study was to prove the effectiveness of virgin coconut oil by determining its exposure time at concentration of $25 \%$ to inhibit growth of oral Candida albicans. Method: The research was done by quasi experiment design using the serial dilution method. The exposure time test was performed using a spread plate technique with virgin coconut oil at concentration of $25 \%$ against oral Candida albicans isolated from saliva. Intervals of day $0,1,2$, and 3 were used. Result: The result showed that virgin coconut oil inhibited the growth of oral $C$. albicans cells at day 2. Conclusion: Virgin coconut oil with concentration of $25 \%$ was able to inhibit with 2 days time exposure, which is similar with other synthetic antifungals.
\end{abstract}

Keywords: Virgin coconut oil, Candida albicans, exposure time

\section{INTRODUCTION}

Coconut oil is a type of tropical oil that has been used for centuries in traditional diets and remedies. ${ }^{1}$ There are two types of coconut oil available in the market, virgin coconut oil (VCO) and refined, bleached, and deodorized (RBD) coconut oil, those are differentiated by the process in making them. ${ }^{1,2}$

VCO is the purest form of coconut oil; water clear or colorless appearance obtained from the fresh coconut meat is extracted by wet process at mild temperatures. ${ }^{3}$ This temperature is used in order to prevent the natural biologically active components of VCO, such as tocopherols and polyphenols, to be inactivated. ${ }^{3}$ The process will preserve all the beneficial nutrients in virgin coconut oil, such as vitamin E, for it to have various functions and a fresh coconut aroma. 1 On the other hand, RBD coconut oil is a yellowish, odorless, and tasteless coconut oil, extracted from coconut meat that undergoes a dry process by first exposing it to sunlight or very high temperatures for several days. The unrefined oil will be extracted from the dry coconut meat (copra) by expression or prepress solvent-extraction methods, followed by the refining, bleaching, and deodorization process. ${ }^{4}$ Since, the RBD coconut oil has underwent 
some process until it can be consumed allows the product to be susceptible to contamination and oxidative rancidity. ${ }^{5}$ Therefore, VCO is richer in nutrients and is a purer form of coconut oil compared to RBD coconut oil.

In the medical field, VCO is proved that can prevent occurance of heart disease and infectious diseases. This oil is easily digested, stimulates metabolism, boosts energy, prevents deposition of fat and improves absorption of vitamins, minerals and amino acids. It also possesses antiinflammatory, anti-microbial and antioxidant properties and can boost the immune system. ${ }^{1}$ At present, virgin coconut oil is said to have antibacterial, antiviral and antifungal properties. ${ }^{1}$ A case treated by Dayrit proves that virgin coconut oil consumed by patients with HIV reduces the viral load, and it also eliminates secondary bacterial, viral, and fungal infections. ${ }^{1}$ Virgin coconut oil has also proved to be an effective adjunctive therapy for paediatric community acquired pneumonia. It accelerates the normalization of respiratory rate and resolution of crackles $^{6}$, can act as an immunoregulator, a defence regulator and regulate body to work and function better. ${ }^{1}$ People who rely on coconut as the primary source of fat in their diets have a remarkably low rate of heart disease. ${ }^{1}$ In addition, virgin coconut oil has proven to have an antioxidant property which prevents protein, lipids and DNA damage by scavenging for free radicals and detoxifying the organism. ${ }^{5}$ Thus, it can be concluded that virgin coconut oil has many benefits in the medical field.

VCO has many effect medically because it posseses various powerful ingredients. It contains the highest percentage of medium chain fatty acids (MCFA) with consist of a carbon-chain length of 8 to 12 carbon atoms. The highest composition of medium chain fatty acid in virgin coconut oil is lauric acid followed by myristic acid, palmitic acid, capric acid, caprylic acid, oleic acid, stearic acid, linoleic acid, and caproic acid. ${ }^{2}$ These fatty acids and their 1-monoglycerides have been proven to kill C. albicans. ${ }^{7}$ Virgin coconut oil has also been proven to have antifungal effects against clinical specimens of all Candida species. ${ }^{8}$ Fatty acids are carboxylic acid with a long unbranched aliphatic tail, derived from or contained in an esterified form of an animal or vegetable fat, oil or wax, which may be saturated or unsaturated such as lauric acid, myristic acid, palmitic acid, capric acid, caprylic acid, oleic acid, stearic acid, linoleic acid, and caproic acid. ${ }^{9}$ These fatty acids will be converted into their corresponding 1-monoglycerides by the body. The capric acid causes the fastest and most effective killing of all three strains of $C$. albicans tested followed by lauric acid and monocaprin. ${ }^{7}$ Capric acid may causes inhibition of $C$. albicans filamentation and reduces candidal adhesion and biofilm formation. ${ }^{10}$ Ingested capric acid will be converted into monocaprin, which is proven to have antimicrobial activity against enveloped viruses, certain bacteria and C. albicans. ${ }^{11}$ It is obvious that the researches done above shows that capric acid and lauric acid, which are present in virgin coconut oil, can act as an effective antimicrobial agents, more specifically antifungal agent. ${ }^{1}$

Currently, the most related and significant research on virgin coconut oil is the research done by Ogbolu and team. They found that the antimicrobial effects of coconut oil against 17 clinical specimens of Candida species strains in Ibadan, Nigeria, were proven to be as effective as fluconazole. C. albicans has $100 \%$ susceptibility to coconut oil with a minimum inhibitory concentration of $25 \%$ ( $1: 4$ dilution). ${ }^{8}$ Therefore, based on the information above, it is necessary to determine the time needed by VCO to against C. albicans.

\section{METHODS}

The research was done by quasi experiment design using the serial dilution method and spread plate technique to find out the exposure time needed for virgin coconut oil to have antifungal effect on oral Candida albicans. ${ }^{12}$ Saliva samples were collected from dental students. The sample was taken by asking students to spit into a petri dish. After collecting the sample, each sample was transferred into a petri dish ready with Sabouraud dextrose agar medium by streak-plate method. The process is repeated for all samples. All the petri dishes were incubated for $24-48$ hours at $37^{\circ} \mathrm{C}$ in a facultative anaerobic environment. ${ }^{13,14}$ Since then the colony characterized by a creamy white colony, flat or hemispherical in shape with a beerlike aroma will be observed and the colony was subsequently tested using the gram staining test. 
Sterile cotton swab was used to transfer a part of the colony to a glass slide, it was fixated and gram staining was done. The glass slide viewed under the microscope showed spherical to oval budding yeast cell, blastospores, and pseudohyphae, proving that the specimen is a Candida species.

A carbohydrate fermentation test was done as confirmation. In test tubes, carbohydrate broth of glucose, maltose, sucrose, lactose, was placed respectively. To all the test tubes, 2 drops of phenol red was added, to observe the color change which indicates acid formation. A Durham tube was inverted in the test tube to trap gas bubble which may form Candida albicans will produce acid and gas when reacted with glucose and maltose, only acid when reacted with sucrose and has no reaction with lactose.

The specific colony of $C$. albicans was identified. This pure C. albicans colony is cultured by streaking it on a slant culture in a test tube which was incubated for 24 hours at $37^{\circ} \mathrm{C}$ in a facultative anaerobic environment.Candida albicans suspension was prepared by adding a colony of $0.5 \times 0.5 \mathrm{~mm}$ in size to $3 \mathrm{ml}$ of physiological salt $(\mathrm{NaCl})$ solution. ${ }^{15}$ This suspension was then compared to the McFarland 0.5 standard.

The McFarland 0.5 standard is used as a reference to observe the turbidity of fungal suspension. The virgin coconut oil is diluted using Polyethyleneglycol (PEG) using the dilution method, yielding virgin coconut oil with the concentration of $50 \%$ and $25 \%$ based on the Table 1 . The amount of virgin coconut oil and PEG needed for each dilution is calculated using the formula $M_{1} V_{1}=M_{2} V_{2}$, where $M_{1}$ is the molarity or concentration of the initial solution, $V_{1}$ is the volume of initial solution to be used, $M_{2}$ is the molarity or concentration of final (diluted) solution and $V_{2}$ is the desired volume of the final dilute solution. ${ }^{16}$ PEG is used as a solvent to dilute the virgin coconut oil as it does not have any antifungal effect and does not change the composition of virgin coconut oil. ${ }^{17}$

The minimum inhibitory concentration is the lowest concentration of virgin coconut oil that is needed to inhibit the growth of oral Candida albicans, which is $25 \% .{ }^{8}$ Once the minimum inhibitory concentration has been determined, the exposure time is determined. Exposure time is the minimum duration of time needed for virgin coconut oil to inhibit the growth of $C$. albicans.A test tube containing $1.0 \mathrm{ml}$ of the MIC of virgin coconut oil is added to $0.1 \mathrm{ml}$ oral $C$. albicans suspension. At the time intervals of 1 day, 2 days, 3 days and 4 days, $0.1 \mathrm{ml}$ of solution is streaked on the Sabouraud dextrose agar petri disc using a spread plate technique. The experiment is repeated 3 times for each interval. The petri discs are incubated at $37^{\circ} \mathrm{C}$ for 24 hours. The shortest duration where there is no fungal growth, will be the optimum exposure time.

\section{RESULTS}

The identified oral $C$. albicans from saliva can be seen in Figure below, round, soft, white or cream coloured colonies with beer-like aroma were observed on the sabouraud dextrose agar medium after incubation for 24 hours.

The procedure proceeded by conducting gram staining on the isolated colonies. The species will be seen as a yeast with round or oval shape, purple in colour under the microscope at magnification of 100 times, as isexhibited in Figure 3 .

Table 2 shows the results of the carbohydrate fermentation test that was done as a confirmation test for the suspected oral $C$. albicans colonies. The colonies obtained from streaking the oral $C$. albicans is shown in Table 3.

Based on the results observed in Figure 4, the growth of oral C. albicans colonies were more

Table 1. Serial dilution of virgin coconut oil

\begin{tabular}{cccc}
\hline Test tube & Polyethylene Glycol & Virgin coconut oil & Concentration (\%) \\
\hline 1 & - & $2.0 \mathrm{ml}$ & 100 \\
2 & $2.0 \mathrm{ml}$ & $2.0 \mathrm{ml}$ from Tube 1 & 50 \\
\hline 3 & $2.0 \mathrm{ml}$ & $2.0 \mathrm{ml}$ from Tube 2 & 25 \\
\hline
\end{tabular}

Note: a) independent t-test, b) Mann Whitney test, significant differences if the $p$-value $<0.05$, highly significant if $p<0.01$; normality test is obtained by the method of Shapiro Wilk, normal distribution of data if $p>0.05$ 
Table 2. Data normality test

\begin{tabular}{|c|c|c|c|c|c|}
\hline Variable & Group & $\mathrm{n}$ & $\mathrm{p}$-value & Data distribution & Comparison test \\
\hline \multirow{2}{*}{ SNA } & Ceph & 32 & 0.344 & Normal & \multirow{2}{*}{ Independent t test } \\
\hline & Manual & 32 & 0.274 & Normal & \\
\hline \multirow{2}{*}{ SNB } & Ceph & 32 & 0.000 & Abnormal & \multirow{2}{*}{ Mann whitney test } \\
\hline & Manual & 32 & 0.000 & Abnormal & \\
\hline \multirow{2}{*}{ ANB } & Ceph & 32 & 0.848 & Normal & \multirow{2}{*}{ Independent $\mathrm{t}$ test } \\
\hline & Manual & 32 & 0.334 & Normal & \\
\hline \multirow{2}{*}{ Mandibular Plane to SN } & Ceph & 32 & 0.943 & Normal & \multirow{2}{*}{ Independent t test } \\
\hline & Manual & 32 & 0.771 & Normal & \\
\hline \multirow{2}{*}{ Occlusal to SN } & Ceph & 32 & 0.649 & Normal & \multirow{2}{*}{ Independent t test } \\
\hline & Manual & 32 & 0.321 & Normal & \\
\hline \multirow{2}{*}{ INA Angle } & Ceph & 32 & 0.098 & Normal & \multirow{2}{*}{ Independent $\mathrm{t}$ test } \\
\hline & Manual & 32 & 0.154 & Normal & \\
\hline \multirow{2}{*}{ INB Angle } & Ceph & 32 & 0.756 & Normal & \multirow{2}{*}{ Independent $t$ test } \\
\hline & Manual & 32 & 0.369 & Normal & \\
\hline \multirow{2}{*}{ Inter Incisal } & Ceph & 32 & 0.864 & Normal & \multirow{2}{*}{ Mann whitney test } \\
\hline & Manual & 32 & 0.000 & Abnormal & \\
\hline \multirow{2}{*}{ INA (mm) } & Ceph & 32 & 0.085 & Normal & \multirow{2}{*}{ Independent $\mathrm{t}$ test } \\
\hline & Manual & 32 & 0.135 & Normal & \\
\hline \multirow{2}{*}{ INB (mm) } & Ceph & 32 & 0.198 & Normal & \multirow{2}{*}{ Independent t test } \\
\hline & Manual & 32 & 0.171 & Normal & \\
\hline
\end{tabular}

Table 2. Cephalometric analysis comparative test for each variable

\begin{tabular}{|c|c|c|c|c|c|}
\hline Variable & Group & $\mathrm{n}$ & Mean (SD) & t count/ & p-value \\
\hline SNA & $\begin{array}{l}\text { Ceph } \\
\text { Manual }\end{array}$ & $\begin{array}{l}32 \\
32\end{array}$ & $\begin{array}{l}81.51(5.95) \\
82.2(6.08)\end{array}$ & $-0.462^{\text {a) }}$ & 0.646 \\
\hline SNB & $\begin{array}{l}\text { Ceph } \\
\text { Manual }\end{array}$ & $\begin{array}{l}32 \\
32\end{array}$ & $\begin{array}{l}77.09(13.18) \\
77.8(13.11)\end{array}$ & $457.000^{b)}$ & 0.460 \\
\hline ANB & $\begin{array}{l}\text { Ceph } \\
\text { Manual }\end{array}$ & $\begin{array}{l}32 \\
32\end{array}$ & $\begin{array}{l}1.93(2.88) \\
2.11(3.08)\end{array}$ & $-0.243^{\text {a) }}$ & 0.809 \\
\hline $\begin{array}{l}\text { Mandibular Plane } \\
\text { to SN }\end{array}$ & $\begin{array}{l}\text { Ceph } \\
\text { Manual }\end{array}$ & $\begin{array}{l}32 \\
32\end{array}$ & $\begin{array}{l}32.79(5.86) \\
32.42(6.26)\end{array}$ & $0.245^{\text {a) }}$ & 0.807 \\
\hline Occlusal to SN & $\begin{array}{l}\text { Ceph } \\
\text { Manual }\end{array}$ & $\begin{array}{l}32 \\
32\end{array}$ & $\begin{array}{c}18.86(5.8) \\
18.47(5.54)\end{array}$ & $0.279^{\text {a) }}$ & 0.781 \\
\hline INA Angle & $\begin{array}{l}\text { Ceph } \\
\text { Manual }\end{array}$ & $\begin{array}{l}32 \\
32\end{array}$ & $\begin{array}{l}25.49(10.48) \\
27.09(10.45)\end{array}$ & $-0.615^{\text {a) }}$ & 0.541 \\
\hline INB Angle & $\begin{array}{l}\text { Ceph } \\
\text { Manual }\end{array}$ & $\begin{array}{l}32 \\
32\end{array}$ & $\begin{array}{l}26.35(7.97) \\
27.67(7.64)\end{array}$ & $-0.676^{\text {a) }}$ & 0.501 \\
\hline Interincisal & Manual & 32 & $\begin{array}{l}126.46 \\
(15.17) \\
\\
117.44 \\
(33.36)\end{array}$ & $459.000^{b)}$ & 0.477 \\
\hline INA (mm) & $\begin{array}{l}\text { Ceph } \\
\text { Manual }\end{array}$ & $\begin{array}{l}32 \\
32\end{array}$ & $\begin{array}{l}7.39(3.25) \\
7.81(3.51)\end{array}$ & $-0.496^{\text {a) }}$ & 0.622 \\
\hline INB (mm) & $\begin{array}{l}\text { Ceph } \\
\text { Manual }\end{array}$ & $\begin{array}{l}32 \\
32\end{array}$ & $\begin{array}{l}6.41(2.35) \\
7.09(2.56)\end{array}$ & -1.111 a) & 0.271 \\
\hline
\end{tabular}

than 50 on day 0 . This represents the time when the yeast is mixed with VCO and directly streaked onto the agar plate. The number of oral $C$. albicans colonies reduced drastically after one day showing repetition 1 and repetition 2 with only growth of one colony while repetition 3 with no growth, which is shown in Figure 5. Based on Figure 6 and 7 , no growth of oral C. albicans colonies were seen after 2 days and 3 days. In conclusion, the growth of oral C. albicans is inhibited by VCO of $25 \%$ concentration within 2 days proved by disappearance of it's colonies from the medium without leaving any of them on that day.

Based on the research results of the effective time of VCO toward oral $C$. albicans can be seen from day 0 to 4 . During day 0 , the number of colonies grown on the agar plates were plentiful, dense and difficult to calculate. On day 1 , it can be seen that the number of colonies reduced drastically showing either 1 colony or no colony and on day 2 and 3, the colonies is no longer seen on the agar plate. This happened might be due to the active ingredients in VCO which inhibited 
Table 3. Cephalometric analysis comparative test with multivariate analysis

\begin{tabular}{ccc}
\hline Statistic tests & Statistic & p-value \\
\hline Pillai's Trace & 0.053 & 0.979 \\
Wilks' Lambda & 0.947 & 0.979 \\
Hotelling's Trace & 0.056 & 0.979 \\
Roy's Largest Root & 0.056 & 0.979 \\
\hline
\end{tabular}

the growth of $C$. albicans which finally causing a fungicidal effect.

VCO is made out of various types of fatty acids such as caproic acid, caprylic acid, capric acid, lauric acid, myristic acid, palmitic acid, stearic acid, oleic acid, linoleic acid, and linolenic acid. $^{2}$ These fatty acids have been proven of providing fungicidal effects toward C. albicans with diverse mechanism of action. Fatty acid naturally inserts themselves into the lipid bilayer of the fungal membranes and physically disturbs the fungal cell membrane resulting in increased fluidity of the membrane which causes a generalized disorganization of the cell membrane that leads to conformational changes in membrane proteins, the release of intracellular components, cytoplasmic disorder and eventually cell disintegration. ${ }^{17}$ Besides that, fatty acids such as capric acid and caprylic acid, lauric acid, act by inhibiting the formation of hyphae which prevents invasion of host cells leading to reduced pathogenicity..$^{9,18}$ Other than that, fatty acids also reduce the $C$. albicans adherence to surfaces of prosthesis, superficial mucosa and medical devices, and have shown the ability to change the expression levels in $C$. albicans genes which reduces the $C$. albicans pathogenicity. ${ }^{9,18}$

The exposure time needed for various antifungals have been proven in many researches. Caspofungin, within 48 hours or 2 days killed more than $99.9 \%$ of C. albicans cells in a biofilm. As for fluconazole plus cyclosporine, a fungicidal effect against $C$. albicans was gradually seen, and within 2 days almost all $C$. albicans cells were killed. On the other hand, Amphotericin $B$ showed a rapid fungicidal effect as the $C$. albicans cells were killed in less than 2 days while $C$. albicans cells in biofilm was inhibited and killed within 2 days. ${ }^{19}$ The exposure time needed is also proportional to the concentration of antifungal used, if a higher concentration was used, the time needed to cause fungicidal effect is lesser. ${ }^{19}$ Based on the researches above, almost all antifungals have an exposure time of 2 days corresponding to the concentration used. VCO has been proven to have antifungal effects against $C$. albicans, with similar mechanism of action as antifungals as Amphotericin B and nystatin. Both VCO and majority of antifungals have the same activity against $C$. albicans, which is by disrupting the fungal cell membrane, increasing cell permeability which leads to cell death, therefore, the time needed to kill the species has a similarity which is 2 days. ${ }^{17}$

\section{CONCLUSION}

Virgin coconut oil with concentration of $25 \%$ was able to inhibit with 2 days time exposure, which is similar with other synthetic antifungals.

\section{REFERENCES}

1. Fife B. Virgin coconut oil: Nature's miracle medicine. New York: Barnes and Noble; 2006. p. 256.

2. Bawalan DD, Chapman KR. Virgin coconut oil: production manual for micro- and village-scale processing. Food and Agriculture Organization of the United Nations; 2006. p. 112.

3. Songkro S, Sirikatitham A, Sungkarak S, Buaking KJ, Wungsintaweekul, Maneenuan $D$, et al. Characterization of aromatherapy massage oils prepared from virgin coconut oil and some essential oils. J Am Oil Chemists Soc 2009;87:93-107.

4. Grimwood BE, Ashman FE, Little CS, Dendy DAV, Jarman CG. Coconut palm products: their processing in developing countries. Food \& Agriculture Organization of the United Nations; 1976. p. 261.

5. Marina AM, Man YBC, Nazimah SAH, and Amin I. Antioxidant capacity and phenolic acids of virgin coconut oil. Int J Food Scie nutrit 2009;60(2):114-23.

6. Erguiza GS, Jiao AG, Reley M, Ragaza S. The effect of virgin coconut oil supplementation for community-acquired pneumonia in children aged 3 to 60 months admitted at The Philippine Children's Medical Center: a single blinded randomized controlled trial. Pediatr 
Pulmon, Sleep and Crit Care. 2008. Available from: http://meeting.chestpubs.org/cgi/ content/abstract/134/4/p139001. 2008.

7. Bergsson G, Arnfinnsson J, Steingrimsson 0 , and Thormar $\mathrm{OH}$. In vitro killing of Candida albicans by fatty acids and monoglycerides. Antimicrobial Agents Chemother 2001:3209-12.

8. Ogbolu DO, Oni AA, Dainiand OA, Oloko AP. In vitro antimicrobial properties of coconut oil on Candida species in Ibadan, Nigeria. J Medicinal Food 2007;10:384-7.

9. Murzyn A, Krasowska A, Stefanowicz P, Dziadkowiec D, Łukaszewicz M. Capric acid secreted by $S$. boulardii inhibits $C$. albicans filamentous growth, adhesion and biofilm formation. Plos One 2010;5:1-7.

10. Thorgeirsdóttir TO, Kristmundsdóttir T, Thormar H, Axelsdóttir I, Holbrook WP. Antimicrobial activity of monocaprin: a monoglyceride with potential use as a denture disinfectant. Acta Odontologica Scandinavica 2006;64:21-6.

11. Shadish WR, Cook TD, and Campbell DT. Experimental and quasi experimental designs for generalized causal interference. Belmont, Ca; Wadsworth Publishing; 2001. p. 13-7.

12. Samaranayake LP. Essential microbiology for dentistry. London: Churchill Livingstone; 2006. 342pp
13. Radeva E, Indjov B, Vacheva R. In vitro study of the effectiveness of intracanal irrigants on Candida albicans. JIMAB Book 2007;2:3-7.

14. Zumdahl SS, Decoste DJ. Introductory chemistry: A foundation. Pasific Goove, CA: Brooks Cole; 2010. p. 736.

15. Norvisari M. Pengaruh kombinasi basis polietilenglikol 400 dan polietilenglikol 6000 terhadap sifat fisik dan perlepasan asam mefenamat pada sediaan supositoria. Solo: Universitas Muhammadiyah Surakarta. 2008.

16. Larone D. Medically important fungi: a guide to identification. Bel Air: ASM Press; 2002. p. 397.

17. Ramage G, VandeWalle, Bachmann SP, Wickes BL, Lopez-Ribot JL. In vitro pharmacodynamics properties of three antifungal agents against preformed Candida albicans biofilms determined by time-kill studies. Antimicrob Agents Chemother 2002:3634-36.

18. Marchetti O, Entenza JM, Sanglard D, Bille J, Glauser MP, Moreillon P. Fluconazole plus Cyclosporine: a fungicidal combination effective against experimental endocarditis due to Candida albicans. Antimicrob Agents and Chemother 2000:2932-8.

19. Park NH, Kang MK. Antifungal and antiviral agents. In: Pharmacology and therapeutics for dentistry. St. Louis: Mosby; 2004. p. 6. 